\title{
THE ANALYSIS ON THE STAKEHOLDERS OF CONFLICT MITIGATION IN THE WAY KAMBAS NATIONAL PARK, LAMPUNG
}

\author{
Gebyar Andyono 1, Djoko Marsono 2, \\ Ronggo Sadono ${ }^{3}$, M. Ali Imron ${ }^{4}$ \\ 1,2,3,4 Faculty of Forestry, Universitas Gadjah Mada
}

javaneagle@gmail.com

\begin{abstract}
Stakeholders with different interests and influences (power) are related to the human-wild elephant conflict mitigation in the Way Kambas National Park in Lampung. Stakeholders need to manage properly to achieve conflict mitigation objectives optimally. This research was conducted in Way Kambas National Park in Lampung. Data were collected with observations, interviews, and related document studies without involving active participations of related stakeholders and data were analyzed by using descriptive qualitative analysis. This research was conducted from September to December 2016. The identification results showed that there were 11 stakeholders dealing with the human-wild elephant conflict mitigation in Way Kambas National Park. The identified stakeholders were divided into three classifications: (1) subject stakeholders coming from farmer groups and people from buffering villages, (2) key player stakeholders consisting of Way Kambas National Park Institution, regional government (village, district and provincial governments), local partners/non-government organizations (Sumatra Forest Conservation and Wildlife Conservation Society-Indonesia Program), Forum Rembug Desa Penyangga/village discussion forums, and Lampung University, and (3) the context setter stakeholder from a private company (PT. Nusantara Tropical Fruit). This research did not find stakeholder from crowd classification. The relationships between stakeholders showed complementary cooperation. The implication of human-wild elephant conflict mitigation management in Way Kambas National Park is that the stakeholder management to build cooperation and collaboration in the form of communication forums to achieve the objectives of human-wild elephant conflict mitigation in Way Kambas National Park is required.

Keywords: stakeholder, power-interest matrix, actor-linkage matrix, Way Kambas National Park
\end{abstract}

JEL $\quad$ : D02 ; Q56; Q57 ; O17; P48

DOI : : 10.24002/kinerja.v22i1.1567

Received : 11/10/2017 Reviewed : 30/12/2017 Final Version : 13/02/2018 


\section{INTRODUCTION}

Way Kambas National Park is a conservation forest in Indonesia which is located in Lampung province, specifically in East Lampung and Middle Lampung districts, and it has borders with 10 sub districts and 37 buffering villages. Way Kambas National Park is provisioned as a national park by Decree of Minister of Forestry No. 444/Menhut-II/989. Way Kambas National Park has biggest mammalian potentials including Sumatran elephant, Sumatran rhino, Sumatran tiger and tapir (Balai Taman Nasional Way Kambas, 2016).

As a conservation area, which belongs to natural habitat of Sumatran elephant, Way Kambas National Park is not free from varying problems to deal with. One of problems faced by Way Kambas National Park is the conflict between wild elephant and human population inhabiting 23 buffering villages (Nyhus, Tilson and Sumianto, 2000; Hedges, et al., 2005; Perera, 2009). The wild elephants exiting from their areas coming into culturing fields in direct borders with Way Kambas National Park is the most prominent wild animal-human conflict. This conflict occurred in more than 150 days within one year with 5 to 50 elephant population in each single conflict (Way Kambas National Park Institution, 2016). This never stop conflict since 1980s led varying stakeholders to make varying mitigation methods (Hedges and Gunaryadi, 2009). Without mitigation efforts to overcome wild animalhuman conflicts, this will affect and result in the diminishing supports to the conservational efforts made by the national park (Treves, et al., 2006).

The government in its efforts to overcome wild animal disruptions (including wild elephant) to human population issued Regulation of Minister of Forestry number P.48/Menhut-II/2008 concerning Guide to Conflict Mitigation between Human Population and Wild Animals. This regulation states that the cooperation between stakeholders are absolute to exercise in the mitigation efforts for wild animals and human conflicts. In strategy and action plans for Sumatran and Kalimantan elephants in 2007-2017 (Department of Forestry, 2007), it is also emphasized the importance of cooperation between parties with related interests in mitigating human-wild elephant conflict. To find out characteristics of each stakeholder, the stakeholder analysis is required. This stakeholder analysis is required so that all stakeholders can be placed in their respective functions and roles so that mutually agreed solutions can be exercised properly.

Many researches about stakeholder in the natural source management and natural conservation have been conducted (Reed, 2008; Jolibert and Wesselink, 2012), including researches concerning stakeholders in the wild animals-human conflict mitigations (Redpath, et al., 2004; Rust, 2017). Some researches took stakeholders as research subjects concerning wild elephant-animal conflict (Zimmermann, et al., 2009; Hill, 2004; He, et al., 2011). However, a research on the stakeholder analysis in the human-wild elephant conflict mitigation has never been done before. Therefore, the objective of this research was to analyze stakeholders in the human-wild elephant conflict mitigation in the Way Kambas National park. This research is expected to be the considerations for managing human-wild elephant conflict mitigation in the Way Kambas National Park and be a model for 
other conflicts with wild animals. This article will present the stakeholder analysis results in the human-wild elephant conflict mitigation in the Way Kambas National Park.

\section{LITERATURE REVIEW}

Stakeholder by Zidane, et al., (2015) is defined as an individual or organization who is actively involved in an activity program or having common interests or common conflict of interests with the exercise of an activity program or the final results of an activity program of an organization or institution. According to this definition, for the purpose of this research, stakeholder is defined as a person/individual or organization who has an interest that is either in accordance or against with, who is involved wither directly or indirectly to, the objective of the human-wild elephant conflict mitigation in the Way Kambas National Park.

According to Brugha and Varvasovszky (2000), in a company or organization management, it requires analysis on the stakeholders to find out the influences and interests of stakeholders, and how these influences and interests will influence the organization performance. Steps in conducting stakeholder analysis according to Reed, et al. (2009) and Yang, et al. (2011) in common are divided into three categories: 1) identifying stakeholders, 2) mapping and categorizing stakeholders, and 3) studying the relationships between stakeholders. This research exercised these three steps of stakeholder analysis.

Reed, et al. (2009) suggests that stakeholder analysis in natural resource management becomes an approach that is able to strengthen marginal stakeholders so that they can participate in the decision making. Stakeholders in the environment and conservation plans are commonly government representatives, businesses, scientists, land owners, and natural resource users (Vogler, Macey and Sigouin, 2017). In the environment and conservation plans, management needs to balance between protection and natural resource use because each of them will have different interests and influences (Vogler, Macey and Sigouin, 2017).

In the study of forestry and especially concerning conservation area management (national park) in Indonesia, in addition to management development in general, the stakeholder analysis is conducted as a part of conflict settlements amongst the stakeholders' interests. Latupapua (2015) identified stakeholders and their roles and contributions in the Manusela National Park eco-tourism in Middle Maluku. Other stakeholder analyses were also conducted by Roslinda, et al. (2012) to Danau Sentarum National Park management in West Kalimantan, Kadir, et al. (2013) to Bantimurung Bulusarung National Park in South Sulawesi, and Adimu, et al. (2017) in Wakatobi National Park. The stakeholder's role in conservation village model development in Mount Rinjani National Park was studied by Ichsan, et al. (2017). Stakeholder analyses on the conflict of interest settlement in conservation area management were conducted by Handoyo (2015) and Yoserizan and Yesidi (2017) in Tesso Nilo National Park in Riau; by Winara and Mukhtar (2011) in Cederawasih Bay National Park in Papua; and by Prasasti, Basuni, and Sunarminto (2015) in Mount Halimun Salak National Park. 


\section{METHODOLOGY}

\subsection{Research Location and Time}

This research was conducted in Way Kambas National Park, East Lampung district, Lampung province, Indonesia. It was conducted in three months from September 2016 to December 2016. This location was selected because historical reasons that Way Kambas National Park was started in 1974, there were humanwild elephant conflicts of more than 150 days in one year, and there were some institutions besides Way Kambas National Park Institution making efforts for these conflict mitigations (Balai Taman Nasional Way Kambas, 2016).

\subsection{Research Framework}

The conflicts between wild animals and human population may cause lower supports to conservational efforts which had been conducted by the conservation authority such as the National Park. The mitigations efforts which had been made require cooperation between stakeholders. In order that the cooperation to run properly, a stakeholder management needs to do. The first step is to analyze the stakeholders. The stakeholder analysis is based on the three steps suggested by Reed, et al. (2009) and Yang, et al. (2011) consisting of: (1) identifying stakeholders; (2) mapping and classifying stakeholders; and (3) analyzing relationships between stakeholders.

\subsection{Data Collection}

Data were collected with interviews, observations and document studies. Required data in this research were primary and secondary data. The primary data were collected with interviews to selected respondents by using purposive sampling (Kothari, 2004) and observations. The respondent numbers for each stakeholders were two respondents who represented each stakeholder related to human-wild elephant conflict mitigation in Way Kambas National Park. Secondary data were obtained with studying literatures and related documents (Bowen, 2009) from respondents.

\subsection{Data Analysis}

Data analysis of stakeholders' participations in the human-wild elephant conflict mitigation in Way Kambas National park was done with stakeholder analysis based on Reed, et al. (2009) and Yang, et al. (2011) in three steps:

1. Identifying stakeholders from groups or individuals having potentials to affect or be affected by the human-wild elephant conflict mitigation activity. The stakeholder identification was done by collecting data and information with semi-structured interview method and based on the prearranged questions.

2. Mapping and classifying stakeholders by using matrices of interests and influences (Reed, et al., 2009). The matrix composition was based on the description of question for informant and it was stated in the quantitative measure (scores). Scoring was based on the answers upon asked questions in the interview. The quantitative measure to the stakeholder's interest and influence is presented in Table 1. The interest score was based on the 
stakeholder's objective toward the relative success in the human-wild elephant conflict mitigation in Way Kambas National Park. The influence score was based on the existences of three influence instruments: forcing power, compensating power, and conditioning power. These scores were described in an interest-influence graphic with each score serving as a coordinate in the graphic (Reed, et al., 2009).

3. Analyzing relationships between stakeholders was conducted by using ActorLinkage Matrix (Biggs and Matsaert, 1999). Identified stakeholders were tabulated in matrices and presented in table rows and columns to describe relationships between stakeholders. Keywords used in describing these relationships were conflict, complementary, and cooperation (Reed, et al., 2009).

Table 1. Quantitative measures for stakeholders' interest and influence concerning human-wild elephant conflict (HEC) mitigation in Way Kambas National Park

(WKNP)

\begin{tabular}{|c|c|c|}
\hline Interest Score & Criteria & Description \\
\hline 5 & Very high & Very supportive to HEC mitigation in WKNP \\
\hline 4 & High & Supportive to HEC mitigation in WKNP \\
\hline 3 & Moderate & Supportive enough to HEC mitigation in WKNP \\
\hline 2 & Low & Less supportive to HEC mitigation in WKNP \\
\hline 1 & Poor & Not supportive to HEC mitigation in WKNP \\
\hline \multicolumn{3}{|l|}{ Influence Score } \\
\hline 5 & Very high & Very influencing the HEC mitigation in WKNP \\
\hline 4 & High & Influencing the HEC mitigation in WKNP \\
\hline 3 & Moderate & Influencing enough the HEC mitigation in WKNP \\
\hline 2 & Low & Less influencing the HEC mitigation in WKNP \\
\hline 1 & Poor & Not influencing the HEC mitigation in WKNP \\
\hline
\end{tabular}

In addition, collected data were analyzed further by using qualitative descriptive analysis method (Keele, 2011). The use of this method enabled the researcher to find out wide characteristics of the research topic.

\section{RESULT AND DISCUSSION}

\subsection{Stakeholder Identification}

There were 11 stakeholders concerning the human-wild elephant conflict mitigation in Way Kambas National Park. They were Way Kambas National Park Institution (WKNPI), regional governments (village, district, and provincial governments), people (people from buffering villages, farmer groups, and Forum Rembug Desa Penyangga (FRDP)/Buffering Village Discussion Forum), partners of WKNPI: Non-Government Organizations (Sumatran Forest Conservation/KHS and Wildlife Conservation Society-Indonesia Program/WCS-IP), Lampung University and Private (PT. Nusantara Tropical Fruit/PT. NTF). 
The Way Kambas National Park Institution (WKNPI) is a technical operation unit having responsibilities as the area manager and serving as the government extension from Ministry of Living Environment and Forestry. This management is based on the Decree of Ministry of Forestry No. 444/Menhut-II/1989. Way Kambas National Park Institution (WKNPI) is the institution with all responsibilities upon all aspects of Way Kambas National Park area management according to prevailing regulation in Indonesia. However, WKNPI also build partnerships with other institutions with the same missions.

People in buffering village is a stakeholder consisting of people living in the buffering zones of Way Kambas National Park and some of them have agricultural and plantation fields. Some of agricultural and plantation land owners belong to farmer group stakeholder.

Forum Rembug Desa Penyangga (FRDP)/Buffering Village Discussion Forum is a forum which was initiated by the Wildlife Conservation Society-Indonesia Program (WCS-IP) to bridge collaboration of human-wild elephant conflict mitigation program between people in buffering villages, Way Kambas National Park, and regional governments. FRDP consists of heads of buffering villages and it has interests to propose and negotiate mitigation programs and helps to Way Kambas National Park and regional governments.

Regional governments are involved in human-wild elephant conflict mitigation in Way Kambas National Park. They are governments in village, district, and provincial levels. Regional governments legally have responsibilities as parts of coordination teams and task force units in wild animal-human conflict mitigation according to Regulation of Minister of Forestry number P.48/Menhut-II/2008 concerning Guide for Wild Animal-Human Conflict Mitigation. Specifically in Way Kambas National Park, East Lampung government issued Decree of Head of East Lampung District number B.418/07/SK/2014 concerning the Integrated Work Team Formation for Wild Animal Disruption Mitigation in East Lampung district. In provincial level, the governor issued Decree of Lampung Governor number $\mathrm{G} / 009 / \mathrm{III} .03 / \mathrm{HK} / 2008$ concerning the Integrated Work Team Formation for Wild Animal Disruption Mitigation in Lampung province as the base for East Lampung district government to issue Decree of Head of East Lampung District number B.418/07/SK/2014. The termination of Ministry of Forestry and the integration of Natural Resource Conservation Institution in Lampung province made the coordination to be a little bit difficult in provincial level. Temporarily, the roles of ex. Forestry Office was taken over by BAPPEDA (regional development planning institution).

Sumatran Forest Conservation or KHS is the partner of Way Kambas National Park with Elephant Response Unit (ERU) program; a mitigation effort in Way Kambas National Park by using tamed elephants that are controlled by mahouts (elephant rider, trainer, or keeper) from Elephant Training Center in Way Kambas National Park.

Wildlife Conservation Society Indonesian Program (WCS-IP) in the human-wild elephant conflict mitigation in Way Kambas National Park with interests in assisting people, casting out wild elephants from human areas, policy programs connecting 
between Way Kambas National park, regional governments, and people around the regions. People around Way Kambas National Park are encouraged to form Forum Rembug Desa Penyangga (FRDP)/Buffering Village Discussion Forums as representatives from buffering villages affected by human-wild elephant conflict to propose mitigation programs.

Lampung University has an interest for serving community. Lampung University has villages to educate in eco-tourism as a part of efforts in improving community welfare as a compensation for the loss inflicted by wild elephants. PT. Nusantara Tropical Fruit is a stakeholder from private company with an interest that wild elephants not to enter and ruin its plantation.

\subsection{Mapping Stakeholders}

Stakeholders according to Friedman and Miles (2006) can be divided into primary and secondary stakeholders. A primary stakeholder is an individual or organization having access and directly being involved to the resource and objective of a project (in this research the project is the human-wild elephant conflict mitigation in Way Kambas National Park). A secondary stakeholder is an individual or organization having no direct access and not being involved to the resource and objective of a project. By definition, the primary stakeholders in the human-wild elephant conflict mitigation in Way Kambas National park are: Way Kambas National Park Institution, Wildlife Conservation Society Indonesian Program (WCSIP), Sumatran Forest Conservation (KHS), farmer groups, people in buffering villages, Forum Rembug Desa Penyangga (FRDP)/Buffering Village Discussion Forums, and village government. The secondary stakeholders are district government, provincial government, Lampung University, and PT. Nusantara Tropical Fruit.

Those stakeholders have different influences (power) and interests (see Table 2). These influences and interests from respective stakeholder need to manage by Way Kambas National Park Institution by involving each stakeholder so that the human-wild elephant conflict mitigation in Way Kambas National Park will run smoothly. This staholder management can be described in a stakeholder map to help Way Kambas National Park Institution to optimize involvement of each stakeholder (Reed, et al., 2009).

Reed, et al. (2009) divided stakeholders into four in the stakeholder mapping (see Figure 1). Subject is a stakeholder classification with a high interest level but having low influence (power) level. Key player is a stakeholder classification with high interest and influence (power) levels. Crowd is a stakeholder classification with low interest and influence (power) levels. Context setter is a stakeholder classification with low interest level but having high influence (power) level. 


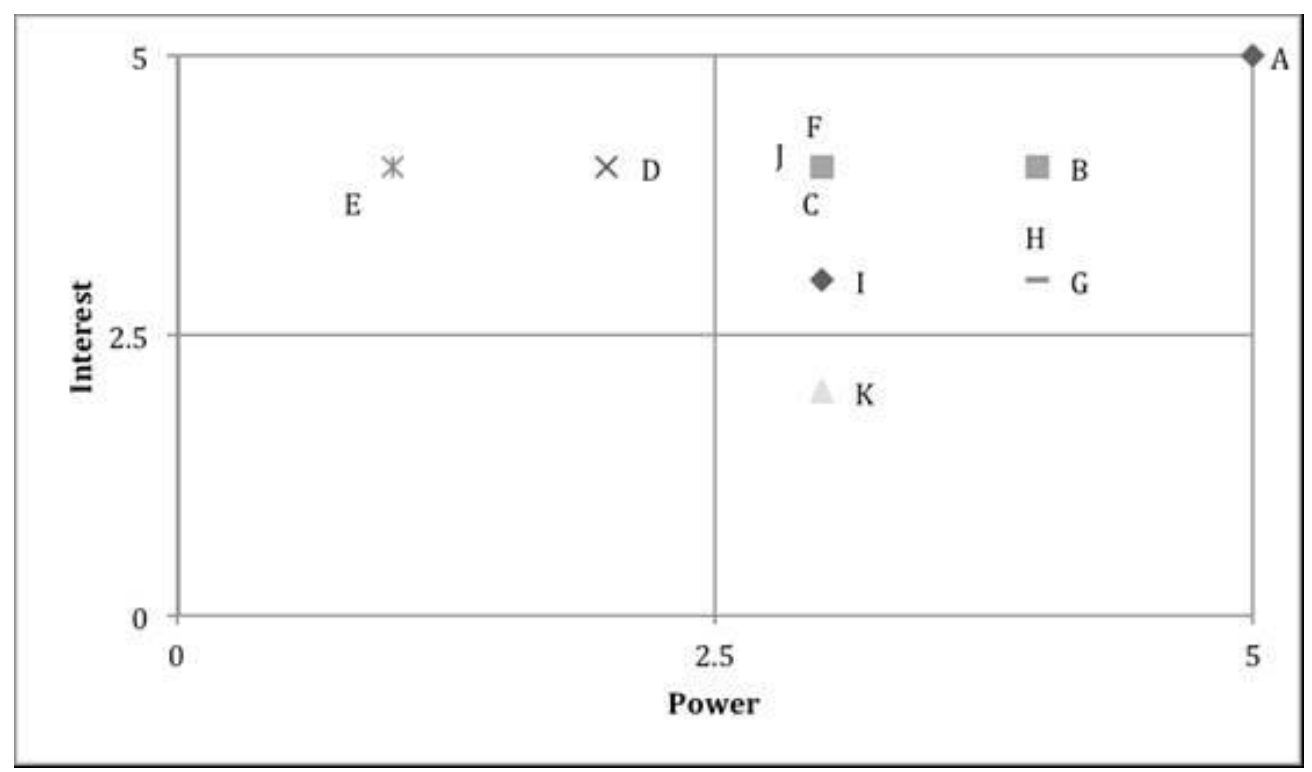

Note:

A: Way Kambas National Park Institution; B: Wildlife Conservation Society-Indonesian Programme;

C: KHS; D: Farmer; E: People; F: Village Government; G: District Government;

H: Provincial Government; I: Lampung University; J: Forum Rembug Desa Penyangga;

K: PT. Nusantara Tropical Fruit

Figure 1. Stakeholder mapping based on interests and power in the mitigation of human-wild elephant conflict in Way Kambas National Park

Table 2. Matrix of analysis of interest and influence (power) in human-wild elephant conflict mitigation in Way Kambas National Park

\begin{tabular}{|c|c|c|}
\hline Stakeholder & Interest & Influence (power) \\
\hline WKNPI & $\begin{array}{l}\text { Area management, authority to the area, } \\
\text { conflict mitigation program }\end{array}$ & +++ \\
\hline Village government & $\begin{array}{l}\text { Conflict mitigation in village level, } \\
\text { protecting people in the village }\end{array}$ & ++ \\
\hline District government & Conflict mitigation in district level & +++ \\
\hline Provincial government & Conflict mitigation in provincial level & +++ \\
\hline People of buffering villages & $\begin{array}{l}\text { Living in the buffering areas, protecting } \\
\text { land and agricultural products }\end{array}$ & + \\
\hline Farmer group & Protecting agricultural products & ++ \\
\hline FRDP & $\begin{array}{l}\text { People representatives of buffering } \\
\text { villages in proposing conflict mitigation } \\
\text { program }\end{array}$ & ++ \\
\hline KHS & $\begin{array}{l}\text { Conflict mitigation by using tamed } \\
\text { elephants }\end{array}$ & ++ \\
\hline WCS-IP & Assisting people in conflict mitigation & ++ \\
\hline Lampung University. & $\begin{array}{l}\text { Authorities in research and public } \\
\text { service }\end{array}$ & ++ \\
\hline $\begin{array}{l}\text { PT. Nusantara Tropical } \\
\text { Fruit }\end{array}$ & Protecting its plantation areas & ++ \\
\hline
\end{tabular}


Stakeholder mapping and its interpretation are used to identify and analyze relationships between stakeholders and effects of their actions in the human-wild elephant conflict mitigation (Zidane, et al., 2015). The subject stakeholders in the human-wild elephant conflict mitigation in Way Kambas National park are farmer groups and people in buffering villages. These stakeholders have high interest to the conflict mitigation, but their influences (power) to give direct effects are low. This low influence can be solved by forming alliance between these stakeholders.

Key player stakeholders in the conflict mitigation are Way Kambas National Park Institution (WKNPI), regional governments (village, district, and provincial levels), local non-government organizations as WKNPI partners (KHS and WCS-IP), Forum Rembug Desa penyangga (FRDP)/buffering village discussion forums and Lampung University. These stakeholders must be managed properly because their high level interests in mitigating human-wild elephant conflict and their influences (power) to make wider mitigation effects.

The context setter stakeholder in this conflict mitigation is PT. Nusantara Tropical Fruit; a stakeholder from private company. This stakeholder is very influential but it has low interest in the human-wild elephant conflict mitigation. Its only interest is to prevent wild elephants entering its plantation areas. However, its high influence (power) in resources can be used to help exercising the wildelephant-human conflict mitigation.

There is no crowd stakeholder classification found related to the conflict mitigation. Crowd stakeholder classification has low levels of interest and influence (power). This is similar to findings in the research by Chinyio and Akintoye (2008) that stakeholders can shift their positions in a particular time according to their interests and influences, and in sometimes they can belong to no classification at all.

The matrix of interests and influences can change along the time according to conditions and its effects of changes should become considerations in the activity management (Reed, et al., 2009). Matrix of interests and influences in Figure 1 is a portrait of stakeholders' conditions in the human-wild elephant conflict mitigation in Way Kambas National Park when this research took place.

\subsection{Relationships between stakeholders in the human-wild elephant conflict mitigation}

The relationships of stakeholder in this research is illustrated by using actorlinkage matrix (Table 3). This method is used to see whether there are any conflict, complementary, or cooperation relationships between stakeholders (Biggs and Matsaert, 1999). 
Table 3. Actor-linkage matrix in human-wild elephant conflict mitigation in Way Kambas National Park (WKNP)

\begin{tabular}{|c|c|c|c|c|c|c|c|c|c|c|c|}
\hline & $\frac{\sum_{z}^{2}}{3}$ & $\begin{array}{l}\frac{a}{1} \\
\text { d } \\
\vdots\end{array}$ & $\frac{O}{\frac{1}{1}}$ & 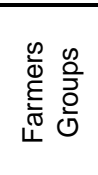 & $\begin{array}{l}\frac{0}{0} \\
\frac{0}{0} \\
0\end{array}$ & 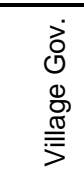 & 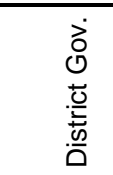 & $\begin{array}{l}\overline{\frac{\pi}{0}} \\
\stackrel{\frac{5}{2}}{0} \overline{0} \\
\frac{0}{0}\end{array}$ & 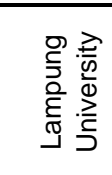 & $\begin{array}{l}\stackrel{0}{0} \\
\text { 妾 } \\
\text { L }\end{array}$ & 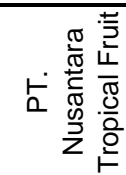 \\
\hline WKNP & & CPR & CPR & Conf. & Conf. & CPR & Compl. & Compl. & CPR & $\overline{C P R}$ & CPR \\
\hline WCS-IP & & & Compl. & $\mathrm{CPR}$ & CPR & CPR & CPR & CPR & CPR & CPR & - \\
\hline KHS & & & & - & - & - & - & - & - & - & - \\
\hline $\begin{array}{l}\text { Farmer } \\
\text { Groups }\end{array}$ & & & & & CPR & CPR & CPR & CPR & CPR & Compl. & - \\
\hline People & & & & & & CPR & CPR & CPR & CPR & Compl. & - \\
\hline $\begin{array}{l}\text { Village } \\
\text { Gov. }\end{array}$ & & & & & & & Compl. & Compl. & CPR & Compl. & - \\
\hline $\begin{array}{l}\text { District } \\
\text { Gov. }\end{array}$ & & & & & & & & Compl. & Compl. & Compl. & - \\
\hline $\begin{array}{l}\text { Provincial } \\
\text { Gov. }\end{array}$ & & & & & & & & & Compl. & Compl. & - \\
\hline $\begin{array}{l}\text { Lampung } \\
\text { University }\end{array}$ & & & & & & & & & & CPR & - \\
\hline FRDP & & & & & & & & & & & - \\
\hline $\begin{array}{l}\text { Pt. } \\
\text { Nusantara } \\
\text { Tropical } \\
\text { Fruit }\end{array}$ & & & & & & & & & & & \\
\hline
\end{tabular}

Descriptions of relationships between actors:

$\mathrm{CPR}=$ cooperation, Conf.$=$ conflict, Compl.$=$ complementary,$-=$ none

Conflict potentials between Way Kambas National Park Institution (WKNPI) and farmer groups and people of villages occurred because farmer groups and people of villages demanded WKNPI responsibilities when wild elephants exited from national park areas and entering their agricultural lands existing in the borders of forest to ruin the crop and plantation. They considered that wild elephants belonged to government and they saw WKNPI as the government representative. Communication and economy improvement aids were programmed by WKNPI as compensations upon loss that the village people suffered.

Good cooperation had been exercised between stakeholder actors related to human-wild elephant conflict mitigation in Way Kambas National Park. This cooperation was manifested in the method of wild elephant casting out with WCS-IP and KHS and the cooperation with Lampung university for public economy improvement with natural environment tourism. The complementary relationships occurred between stakeholders with the same tasks and functions. 


\section{CONCLUSION}

There were 11 identified stakeholders in the human-wild elephant conflict mitigation in Way Kambas National Park. These related stakeholders were divided into three classifications: (1) subject stakeholders coming from farmer groups and people in buffering villages; (2) key player stakeholders including Way Kambas National Park Institution, regional governments (village, district, and provincial levels), partners from local non-government organizations (Sumatran Forest Conservation/KHS and Wildlife Conservation Society-Indonesian Programe/WCSIP), Forum Rembug Desa Penyangga (FRDP)/buffering village discussion forums, and Lampung university; and (3) context setter stakeholder coming from private company (PT. Nusantara Tropical Fruit). This research did not find any stakeholder in crowd classification. The majority of relationships between stakeholders were shown to be cooperation and complementary relationships.

\subsection{Managerial Implication}

Many stakeholders with similar interests in this human-wild elephant conflict mitigation benefits Way Kambas National Park management. The implication is that stakeholder management is required in the wild elephant conflict mitigation in the form of a forum for communication. The objective of this forum is to form harmonious collaboration or cooperation to obtain objectives of human-wild elephant conflict mitigation widely. This is in accordance with researches conducted by Redpath, et al. (2004), Treves, et al. (2006), and Rust (2017).

\subsection{Recommendation}

The management of human-wild elephant conflict mitigation in Way Kambas National Park should be able to maximize potentials that each stakeholder possess. The manager should be able to manage varying interests and influences so that they will synergize in the conflict mitigation processes. The mitigation model by collaboration management can be an alternative to implement. Further researches about collaboration management in the human-wild elephant conflict mitigation are still required. In this research, quantification on the stakeholder relationships are not yet done. Therefore, further researches should quantify these stakeholder relationships. 


\section{REFERENCES}

Adimu, H.E., Boer, M., Yulianda, F., and Damar, A., 2017. The Role of Stakeholders in Marine Conservation Areas in Wakatobi National Park, Indonesia. AACL Bioflux, 10(6), pp.1483-1491.

Balai Taman Nasional Way Kambas, 2016. Rencana Pengelolaan Jangka Panjang Taman Nasional Way Kambas Provinsi Lampung Periode 2017 - 2026.

Biggs, S. and Matsaert, H., 1999. An actor-oriented approach for strengthening research and development capabilities in natural resource systems. Public Administration and Development, 19(3), pp.231-262.

Bowen, G.A., 2009. Document Analysis as a Qualitative Research Method. Qualitative Research Journal, [online] 9(2), pp.27-40.

Brugha, R. and Varvasovszky, Z., 2000. Stakeholder analysis: a review. Health Policy and Planning, [online] 15(3), pp.239-246.

Departemen Kehutanan, 2007. Strategi dan Rencana Aksi Konservasi Gajah Sumatera Dan Gajah Kalimantan 2007-2017. Jakarta.

Friedman, A.L. and Miles, S., 2006. Stakeholder - Theory and Practice. New York: Oxford University Press.

Handoyo. 2015. Resolusi Konflik di Taman Nasional Tesso Nilo, Riau, Indonesia: Tinjauan Relasi Pemangku Kepentingan. Jurnal Analisis Kebijakan Kehutanan, 12(2), pp.89-103

He, Q., Wu, Z., Zhou, W. and Dong, R., 2011. Perception and attitudes of local communities towards wild elephant-related problems and conservation in Xishuangbanna, Southwestern China. Chinese Geographical Science, [online] 21(5), pp.629-636.

Hedges, S. and Gunaryadi, D., 2009. Reducing human-elephant conflic: do chillies help deter elephants from entering crop fileds? Oryx, [online] 44(1), pp.139146.

Hedges, S., Tyson, M.J., Sitompul, A.F., Kinnaird, M.F., Gunaryadi, D. and Aslan, 2005. Distribution, status, and conservation needs of Asian elephants (Elephas maximus) in Lampung Province, Sumatra, Indonesia. Biological Conservation, [online] 124(1), pp.35-48.

Hill, C.M., 2004. Farmers' perspectives of conflict at the wildlife-agriculture boundary: Some lessons learned from African subsistence farmers. Human Dimensions of Wildlife, [online] 9, pp.279-286.

Ichsan, A.C., Soekmadi, R., Adiwibowo, S., and Kusmana, C., 2017. Peran Pemangku Kepentingan dalam Pelaksanaan Model Desa Konservasi di Taman Nasional Gunung Rinjani. Jurnal Analisis Kebijakan Kehutanan, 
14(1), pp.47-59.

Jolibert, C. and Wesselink, A., 2012. Research impacts and impact on research in biodiversity conservation: The influence of stakeholder engagement. Environmental Science and Policy, [online] 22, pp.100-111.

Kadir, A.W., Awang, S.A., Purwanto, R.H., and Poedjirahajoe, E., 2013. Stakeholder Analysis of Bantimurung Bulusaraung National Park Management, South Sulawesi Province. Jurnal Manusia dan Lingkungan. 20(1), pp.11-21.

Keele, R., 2011. Chapter 3 - Quantitative versus Qualitative Research, or Both? In: Nursing Research and Evidence-Based Practice. Jones \& Bartlett Learning, pp.35-52.

Kothari, C.R., 2004. Research Methodology: Methods and Techniques. second ed. New Age International $(P) L t d$. New Delhi: New Age International $(P) L t d$.

Latupapua, Y.T., 2015. Implementasi Peran Stakeholder dalam Pengembangan Ekowisata di Taman Nasional Manusela (TNM) di Kabupaten Maluku Tengah. Jurnal Agroforestri, 10(1), pp.21-30.

Nyhus, P.J., Tilson, R. and Sumianto, 2000. Crop raiding Elephants and Conservation Implications at Way Kambas National Park, Sumatra, Indonesia.pdf. Oryx, 34(4), pp.262-274.

P.48/Menhut-II/2008 tentang Pedoman Penanggulangan Konflik antara Manusia dan Satwa Liar.

Perera, B.O., 2009. The human-elephant conflict: A review of current status and mitigation methods. Gajah, [online] 30, pp.41-52.

Prasasti, B.G., Basuni, S., Sunarminto, T., 2015. Strategi Penyelesaian Konflik Penguasaan Lahan di Lokapurna Taman Nasional Gunung Halimun Salak. Media Konservasi, 20(1), pp.40-47.

Redpath, S.M., Arroyo, B.E., Leckie, F.M., Bacon, P., Bayfield, N., Gutierrez, R.J. and Thirgood, S.J., 2004. Using Decision Modeling with Stakeholders to Reduce Human-Wildlife Conflict: A Raptor-Grouse Case Study. Conservation Biology, 18(2), pp.350-359.

Reed, M.S., Graves, A., Dandy, N., Posthumus, H., Hubacek, K., Morris, J., Prell, C., Quinn, C.H. and Stringer, L.C., 2009. Who's in and why? A typology of stakeholder analysis methods for natural resource management. Journal of Environmental Management, 90(5), pp.1933-1949.

Reed, M.S., 2008. Stakeholder participation for environmental management: A literature review. Biological Conservation, 141(10), pp.2417-2431.

Roslinda, E., Darusmana, D., Suharjito, D., and Nurrochmat, D.R., 2012. Analisis 
Pemangku Kepentingan dalam Pengelolaan Taman Nasional Danau Sentarum Kabupaten Kapuas Hulu, Kalimantan Barat. Jurnal Manajemen Hutan Tropika, 18(2), pp.78-85.

Rust, N.A., 2017. Can stakeholders agree on how to reduce human-carnivore conflict on Namibian livestock farms? A novel Q-methodology and Delphi exercise. Oryx, [online] 51(02), pp.339-346.

Treves, A., Wallace, R.B., Naughton-Treves, L. and Morales, A., 2006. Comanaging human-wildlife conflicts: a review. Human Dimensions of Wildlife, [online] 11, pp.383-396.

Vogler, D., Macey, S. and Sigouin, A., 2017. Stakeholder Analysis in Environmental and Conservation Planning. Lessons in Conservation, 7, pp.5-16.

Winara, A., and Mukhtar, A.S., 2011. Potensi Kolaborasi dalam Pengelolaan Taman Nasional Teluk Cenderawasih di Papua. Jurnal Penelitian Hutan dan Konservasi Alam, 8(3), pp.217-226.

Yang, J., Shen, G.Q., Bourne, L., Ho, C.M. and Xue, X., 2011. A typology of operational approaches for stakeholder analysis and engagement. Construction Management and Economics, 29(2), pp.145-162.

Yoserizal dan Yesi. 2017. Conflict of Interest among Stakeholders in Tesso Nilo National Park (TNNP). Jurnal Antropologi, 19(2), pp.101-107.

Zidane, Y.J.T., Johansen, A., Ekambaram, A. and Hald, L.C., 2015. When Stakeholders Shape Successes or Bring Failures - A Case Study of an Algerian Megaproject. Procedia Computer Science, [online] 64(1877), pp.844-851.

Zimmermann, A., Davies, T.E., Hazarika, N., Wilson, S., Chakrabarty, J., Hazarika, B. and Das, D., 2009. Community-Based Human-Elephant Conflict Management in Assam. Gajah, [online] (30), pp.34-40. 